\title{
BMJ Open Welfare state retrenchment and increasing mental health inequality by educational credentials in Finland: a multicohort study
}

\author{
Lauri Kokkinen, ${ }^{1}$ Carles Muntaner, ${ }^{2}$ Anne Kouvonen,, ${ }^{3,4,5}$ Aki Koskinen, ${ }^{1}$ \\ Pekka Varje, ${ }^{1}$ Ari Väänänen ${ }^{1}$
}

To cite: Kokkinen $\mathrm{L}$, Muntaner C, Kouvonen A, et al. Welfare state retrenchment and increasing mental health inequality by educational credentials in Finland: a multicohort study. BMJ Open 2015;5:e007297. doi:10.1136/bmjopen-2014007297

- Prepublication history for this paper is available online. To view these files please visit the journal online (http://dx.doi.org/10.1136/ bmjopen-2014-007297)

Received 25 November 2014 Revised 27 April 2015 Accepted 29 April 2015

CrossMark

For numbered affiliations see end of article.

Correspondence to Dr Lauri Kokkinen; lauri.kokkinen@ttl.fi

\begin{abstract}
Objectives: Epidemiological studies have shown an association between educational credentials and mental disorders, but have not offered any explanation for the varying strength of this association in different historical contexts. In this study, we investigate the education-specific trends in hospitalisation due to psychiatric disorders in Finnish working-age men and women between 1976 and 2010, and offer a welfare state explanation for the secular trends found.
\end{abstract}

Setting: Population-based setting with a $25 \%$ random sample of the population aged $30-65$ years in 7 independent consecutive cohorts (1976-1980, 19811985, 1986-1990, 1991-1995, 1996-2000, 20012005, 2006-2010).

Participants: Participants were randomly selected from the Statistics Finland population database $(n=2865746)$. These data were linked to diagnosisspecific records on hospitalisations, drawn from the National Hospital Discharge Registry using personal identification numbers. Employment rates by educational credentials were drawn from the Statistics Finland employment database.

Primary and secondary outcome measures: Hospitalisation and employment.

Results: We found an increasing trend in psychiatric hospitalisation rates among the population with only an elementary school education, and a decreasing trend in those with higher educational credentials. The employment rate of the population with only an elementary school education decreased more than that of those with higher educational credentials.

Conclusions: We propose that restricted employment opportunities are the main mechanism behind the increased educational inequality in hospitalisation for psychiatric disorders, while several secondary mechanisms (lack of outpatient healthcare services, welfare cuts, decreased alcohol duty) further accelerated the diverging long-term trends. All of these inequality-increasing mechanisms were activated by welfare state retrenchment, which included the liberalisation of financial markets and labour markets, severe austerity measures and narrowing down of public sector employment commitment.

\section{Strengths and limitations of this study}

- This paper links welfare state theory to mental health outcomes.

- Strengths include the population-based setting with individual-level data on hospitalisations, time span of 35 years and the size of the cohorts.

- Major limitations of this study are its reliance on aggregate-level data on employment rates and its inability to take all theoretically possible confounding factors, such as social support and childhood socioeconomic position, into account.

\section{INTRODUCTION}

Evidence shows that socioeconomic position plays a major role in various types of psychopathology. ${ }^{1}{ }^{2}$ For example, in the 1980s in Finland, hospitalisation for some psychiatric diagnoses was two times higher among those with less than 10 years of formal education compared with those with more than 12 years of formal education. ${ }^{3}$ Historically, the rate of psychiatric hospital admissions in a population has been associated with social factors such as urban environment, ${ }^{4}$ economic cycles $^{5}$ and unemployment, ${ }^{6}$ and is considered to be one indicator of population mental health. ${ }^{7}$ Currently, mental disorders account globally for a quarter of all years lived with disability. ${ }^{8}$ Nevertheless, research on education-specific long-term trends in severe psychiatric disorders is rare. To the best of our knowledge, no previous study has examined long-term changes in national hospitalisation trends for psychiatric disorders by educational credentials. Furthermore, our study was also motivated by a recent paper showing that there was no educational gradient in mental illness among monks and nuns in cloisters. ${ }^{9}$ This might suggest that educational credentials do not play an important role outside market economies, and that in 
market economies the association between education and severe psychiatric disorders might be strongly determined by available labour market positions.

\section{Welfare state retrenchment and mechanisms increasing inequality}

In all democratic societies, the acceptable level of inequalities is set in politics, ${ }^{10}$ and even the advanced welfare state economies have different levels of health inequality due to their different political traditions. ${ }^{11} 12$ The Finnish welfare state was created as a particular polity under Social Democratic and Agrarian League-ruled governments in a specific geopolitical position-between the East and the West-in the early post-war period as a way of structuring the labour market and regulating capitalism. Although the phrase 'welfare state' is in conventional epidemiological studies used in a narrow sense to refer to provision of welfare services and social transfers, we consider it more broadly as a specific form of state balancing the power between labour and capital, and structuring the society and its stratifications. ${ }^{13}$ Furthermore, we argue that it is very difficult to understand the changing impact of educational credentials on psychiatric disorders without understanding the significance and role of education in the broader political and labour market context.

Even if the foundation for the Finnish welfare state was set right after World War II, Finland did not implement most of the universal 'Nordic' policies until the 1960 s and 1970 s, decades after Sweden and Denmark. ${ }^{14}$ In Finland, universal Health Insurance was adopted as late as 1964. It was based on the German model, including sickness allowances (compensation for loss of income during incapacity for work) and an insurance compensation covering a share of the costs of private healthcare service use, medicines and illness-related transportation. In order to achieve educational equality without selecting or streaming students during their basic education, Finland introduced a compulsory 9-year comprehensive school with no tuition fees and with free school meals and subsidised transportation services in 1972. By 1977, the comprehensive school system covered the whole of Finland and has remained without major reforms ever since. In order to achieve equity in health services coverage, Finland adopted the Public Health Law in 1972. This law primarily introduced tax-funded municipal health centres as the basic unit of service provision for all citizens. The Occupational Health Convention in 1971 had only included people with permanent job contracts, and the Health Insurance Law in 1964 had only met the health service needs of those living in Southern Finland who were able to pay the deductibles when purchasing services from the private sector.

Finnish financial markets remained closed until 1986, when the Bank of Finland decided to suddenly liberalise the financial markets without any public debate..$^{15} 16$ Prior to 1986, financing from foreign investors was subject to license. The abrupt liberalisation of financial markets led to massive lending of cheap money by Finnish banks and businesses, and also the amount of loans per citizen rose by over $100 \%$ within a year. This situation of loose money led to a textbook example of a casino economy: the speculative increase in the value of houses, offices and stocks, and the birth of a stock market bubble capitalised by market predators. ${ }^{17}$ After the burst of the bubble, the overpriced houses lost over one half of their value between 1989 and 1993, whereas the mortgage rates rose even 5-fold, and the unemployment rate increased from $3.5 \%$ to $18 \%{ }^{18}$ During the economic crisis, almost 400000 people lost their jobs, and those hardest hit by the recession were the people with low educational credentials.

Even if the size of the Finnish public sector or social expenditure never rose above the Organisation for Economic Co-operation and Development average during the golden age of the $1980 \mathrm{~s},{ }^{19}$ the expansion of the welfare state was claimed to be the root cause for Finnish financial problems, and the economic recession opened a window of opportunity for severe austerity policies. ${ }^{20}$ The conservative government of 1991-1995 implemented considerable spending cuts that were not allocated evenly across all public spending but were more heavily concentrated on services for people with the least power to resist them: the non-working population. ${ }^{21}$ The level of unemployment benefits was lowered and the Health Insurance was affected by decreasing the sickness allowances and raising the deductibles of medicines. ${ }^{22}$ In addition, the state subsidy for municipal healthcare provision was cut. As a result, access to healthcare services became more difficult for those not having access to occupational healthcare, or those not able to pay the deductibles for using the private sector services. In 1999, Finnish residents already paid $20 \%$ of their healthcare costs out of pocket, compared with, for example, $16 \%$ in the USA. ${ }^{23}$

Along with these severe cuts to health and social care services and welfare, labour market liberalisation, ${ }^{24}$ increasing transfer of manufacturing and blue-collar jobs out of Finland, ${ }^{25}$ and the narrowing down of public sector employment commitment ${ }^{26}$ made the labour market position of those with only an elementary school education more vulnerable. As a result, the core labour force became more highly educated, the labour markets became more selective based on educational credentials, and the social mobility diminished especially for those with the lowest educational credentials. ${ }^{27-29}$ All in all, the economic crisis rapidly accelerated welfare state retrenchment that had already been on the neoliberal agenda from the beginning of the $1980 \mathrm{~s},{ }^{30}$ and started reshaping the Finnish society and its social stratification. The income inequality between population groups grew significantly, but the most radical restructuring took place between labour and capital. Whereas labour income as a percentage of national income in Finland was as high as $76 \%$ in 1991, it was only $57 \%$ in 2000 , at the same level as right after World War II. ${ }^{31}$ 
After the economic crisis, the coalition government in 1995-1999 did not introduce any radical policy changes. The same applies to the three succeeding governments between 1995 and 2010, which continued the incremental welfare state restructuring within the pre-existing policy paradigms towards labour market flexibility, welfare pluralism, supply side economics, and efforts at minimising social expenditures. ${ }^{32}{ }^{33}$ However, the accession to the European Union (EU) in 1995 meant that the legislation governing many health policy decisions was now determined by the EU, and national powers of decision-making were limited in scope. For example, the Finnish alcohol policy changed dramatically overnight when Estonia joined the EU in 2004. Fearing a considerable increase in Finnish visitors' import of alcohol from Estonia due to free movement of goods, Finland decreased its alcohol excise duty rates by $33 \%$, and within a year alcohol-related mortality rose by $20 \% ;{ }^{34}$ the most notable increase was among those in the social classes with lower income. ${ }^{35}$

\section{The aim of the study}

In this study, we first described the welfare state retrenchment in Finland (liberalisation of financial and labour markets, efforts for minimising social expenditures and narrowing down of public sector employment commitment). We also identified the main mechanism (low employment opportunities leading to low income and job insecurity) and secondary mechanisms (lack of outpatient healthcare services, welfare cuts and decreased alcohol duty) through which this changing macro-context might deteriorate the mental health of those with low educational credentials. We examine the plausibility of those mechanisms with the analysis of education-specific trends in employment rates and hospitalisation due to psychiatric disorders among Finnish men and women aged 30-65 years between 1976 and 2010. In the Discussion section, we will then describe the potential role of the secondary mechanisms explaining these secular trends. Our hypothesis is that even if the Finnish comprehensive school system has offered tax-funded and uniform basic education for the whole population since the 1970s, the welfare state retrenchment and its education-specific impacts have produced an increasing rate of psychiatric hospitalisations among those with low educational credentials. We predict that not even one of the world's most egalitarian comprehensive school systems has been able to prevent increasing educational inequalities in mental health outcomes under this rapidly changing political and economic context. Furthermore, the global economic crisis after 2008 may have further increased hospitalisation for psychiatric disorders among those with low educational credentials.

\section{METHODS}

Databases

The individual-level data were obtained from a population database maintained by Statistics Finland, in which every Finnish resident is registered under a personal identification number. From these data, we selected a $25 \%$ random sample of the population aged 18-64 years with a recorded occupational title in seven independent consecutive cohorts (1976-1980, 1981-1985, 1986-1990, 1991-1995, 1996-2000, 2001-2005, 2006-2010). This study included only those aged 30 years or over $(n=2$ 865746 ), because in Finland education is usually completed by this age. Education was measured at the start of the follow-up, with the same classifications used at all points of measurement. The participants were categorised according to their highest completed educational credentials: (1) elementary school or lower, (2) secondary education, and (3) college degree or higher. Information on the age and sex of the participants was collected from the population database. Table 1 presents the background characteristics of the participants.

Data on hospitalisations were obtained from the National Hospital Discharge Register (NHDR) maintained by the National Institute for Health and Welfare. Every person permanently residing in Finland who has received hospital treatment in a public sector hospital is recorded in this register with a personal identification number. The NHDR has been shown to cover the hospitalisation rates of the Finnish population well and to register hospitalisation rates accurately, and this high accuracy also applies to psychiatric diagnoses. ${ }^{36}$ In this study, we recoded the psychiatric diagnoses categorised according to the International Classification of Diseases (ICD) 8th and 9th revision (codes 291-319) to correspond with the classification of ICD-10 (codes F04-F99). We monitored the NHDR data of the participants collected from the population database over a 5 -year period in each of the seven cohorts. The first register follow-up on hospitalisations started on 1 January 1976 and ended on 31 December 1980 for the first cohort. The follow-up for the second cohort started the next day. The follow-up of the seventh cohort ended on 31 December 2010.

Employment rates for the population aged 30-65 years between 1986 and 2010 were drawn from an employment database maintained by Statistics Finland.

\section{Statistical analysis}

The follow-up began on 1 January at the beginning of each cohort and ended on the day the participant was hospitalised or died. For the rest of the participants, the follow-up period ended 5 years after it began, on 31 December. Annual age-adjusted (age groups 30-34, 35-39, 40-44, 45-49, 50-54, 55-59 and 60-64) incidence rates were calculated during the 5 -year follow-up per 10000 participants separately for men and women in each of the three educational levels in seven independent cohorts $(($ cases $\times 10000) /($ person days/365) $)$. Employment rates (\%) were calculated for five cohorts (1986-1990, 1991-1995, 1996-2000, 2001-2005, 20062010) and are presented separately for men and women stratified by educational credentials. To test the 


\begin{tabular}{|c|c|c|c|c|c|c|c|}
\hline & ङ & 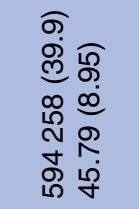 & 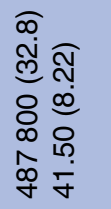 & 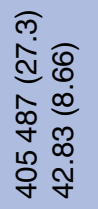 & 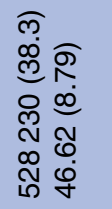 & 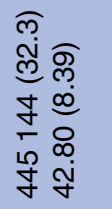 & 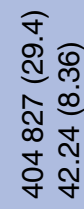 \\
\hline & 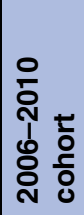 & 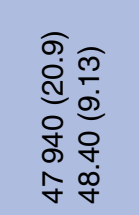 & 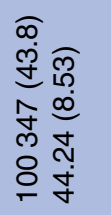 & 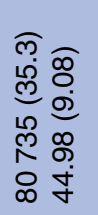 & 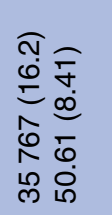 & 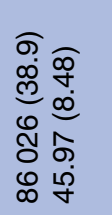 & 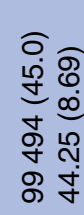 \\
\hline & 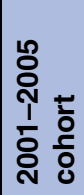 & 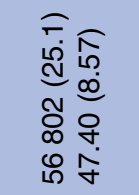 & 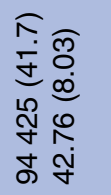 & 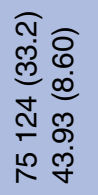 & 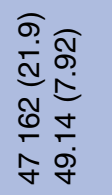 & 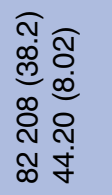 & 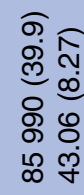 \\
\hline & 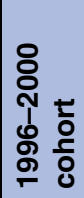 & 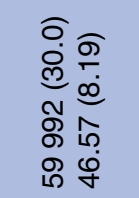 & 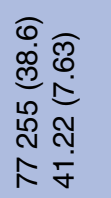 & 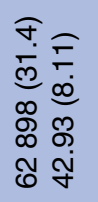 & 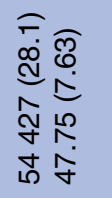 & 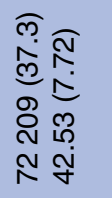 & 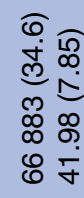 \\
\hline & $\begin{array}{l}\frac{1}{8} \\
\frac{1}{1} \\
\frac{1}{8} \\
\frac{1}{2} \\
\end{array}$ & 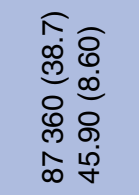 & 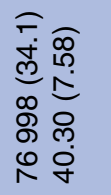 & 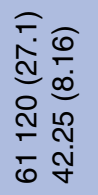 & 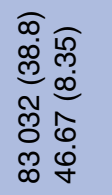 & 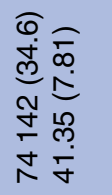 & 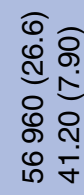 \\
\hline & 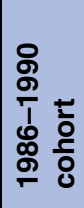 & 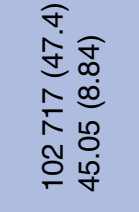 & 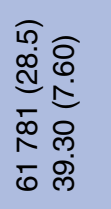 & 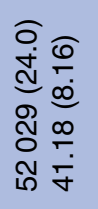 & 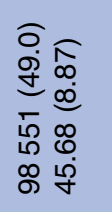 & 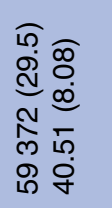 & 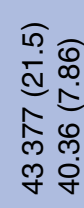 \\
\hline & 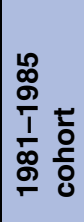 & 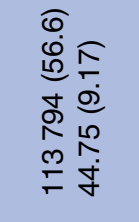 & 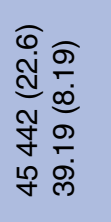 & 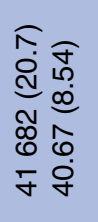 & 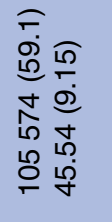 & 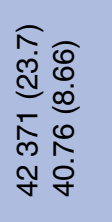 & 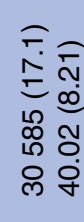 \\
\hline & 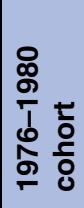 & 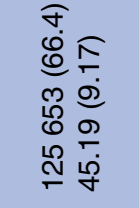 & 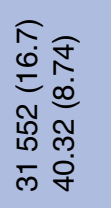 & 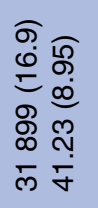 & 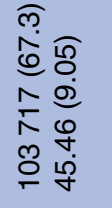 & 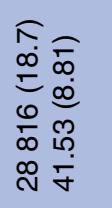 & 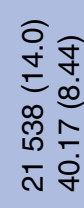 \\
\hline & & 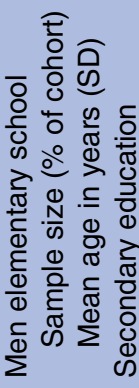 & 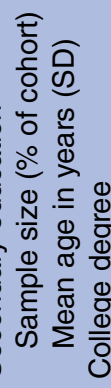 & 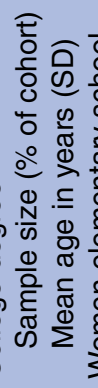 & "ָ & 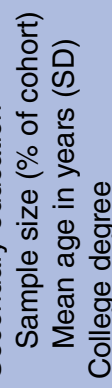 & 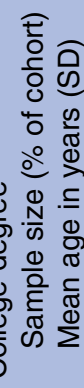 \\
\hline
\end{tabular}

educational differences in hospitalisations, we analysed the education-specific risk of psychiatric disorders within each cohort using Cox proportional hazard models adjusted for age and marital status. Persons with a college degree were used as the reference group. The results are communicated as HRs and their $95 \%$ CI. The analysis was performed using the SAS V.9.2 program package and the IBM SPSS Statistics for Windows, V.20.0 software package.

\section{RESULTS}

The decreasing number of the working age population with only an elementary school education in Finland between 1976 and 2010 was clearly evident in our data when the participants' educational credentials were compared between the cohorts. Between the first (1976-1980) and the last (2006-2010) cohorts, the proportion of those with only an elementary school education decreased from $66.8 \%$ to $18.6 \%$ (table 1 ).

Figure 1 shows the employment rates and the age-adjusted incidence rates for psychiatric hospitalisation per 10000 individuals, separately for men and women, stratified by educational credentials. Among men with an elementary school education, the age-adjusted incidence rate decreased from 38 in 19761980 to 32 in 1986-1990, then increased to 45 in 1990 1995 and remained fairly stable until 2006-2010 (percentage increase during 1976-2010 being 17\%). The employment rate for men with an elementary school education decreased from $67 \%$ in $1986-1990$ to $55 \%$ in 1990-1995 and remained fairly stable until 2006-2010 (percentage decrease during 1976-2010 being 17\%). Among men with secondary education, the incidence rate decreased from 43 in 1976-1980 to 31 in 1981-1986, then increased to 42 in 1991-1995, and decreased again to 36 in 2006-2010 (percentage decrease during 1976-2010 being 15\%). The employment rate for men with secondary education decreased from $83 \%$ in $1986-1990$ to $70 \%$ in $1990-1995$ and then increased to $74 \%$ in 2006-2010 (percentage decrease during 1976-2010 being 12\%).The incidence rate among men with a college degree increased from 29 in $1976-1980$ to 37 in 1986-1990, then decreased to 33 in 1996-2000, and further decreased to 23 in 2006-2010 (percentage decrease during 1976-2010 being 21\%). The employment rate for men with a college degree decreased from $91 \%$ in 1986-1990 to $82 \%$ in 1990-1995 and then increased to $85 \%$ in 2006-2010 (percentage decrease during 1976-2010 being 7\%).

Among women with an elementary school education, the age-adjusted incidence rate increased from 24 in $1976-1980$ to 28 in 1991-1995, then decreased to 22 in 1996-2000, and increased again to 30 in 2006-2010 (percentage increase during 1976-2010 being 29\%). The employment rate for women with an elementary school education decreased from $63 \%$ in $1986-1990$ to $54 \%$ in 1990-1995 and to 50\% in 2006-2010 (percentage 
Incidence rates (per 10000 person-years), men
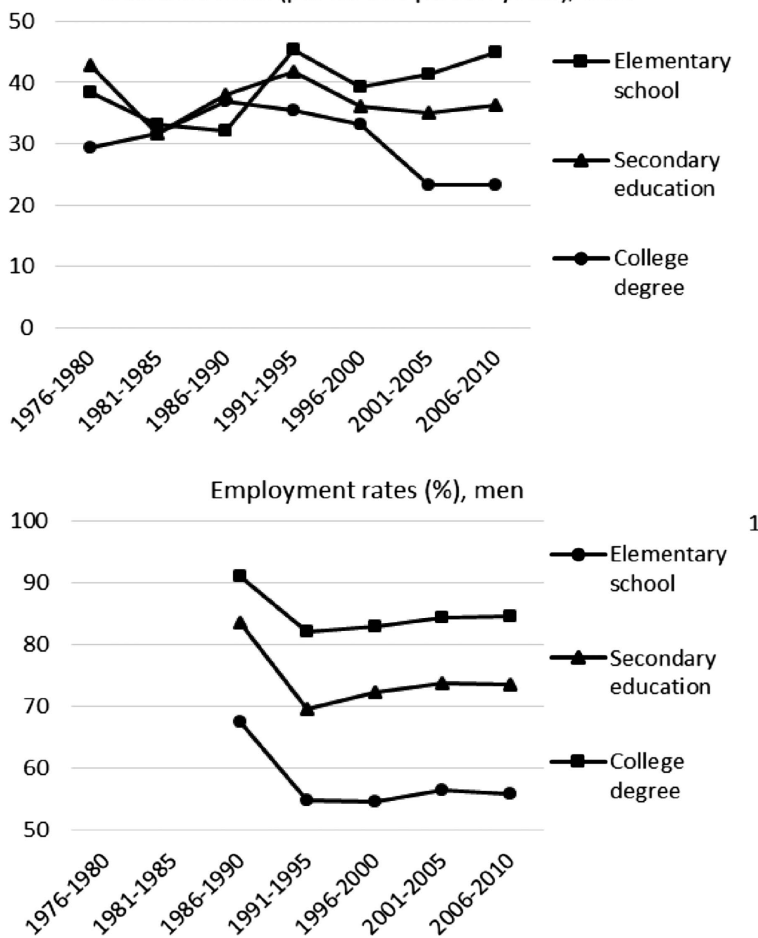

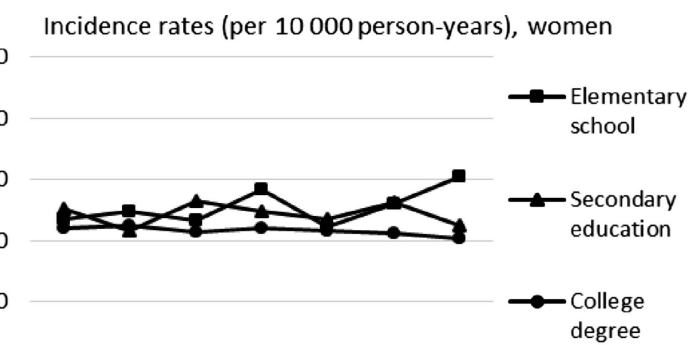

0
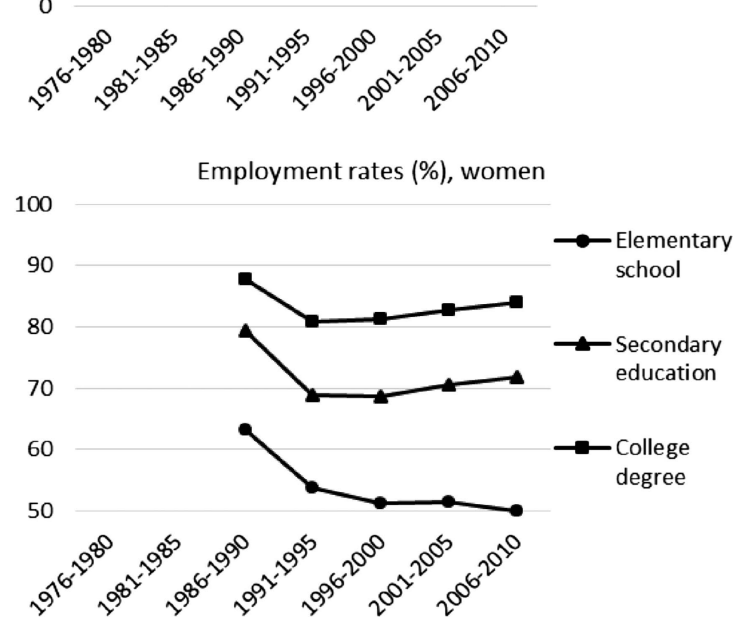

Figure 1 The employment rates in five cohorts and the age-adjusted incidence rates for psychiatric hospitalisation per 10000 individuals in seven cohorts.

decrease during 1976-2010 being 21\%). Among women with secondary education, the incidence rate remained fairly stable over time, at 25 in $1976-1980$ and 22 in 2006-2010 (percentage decrease during 1976-2010 being $11 \%$ ). The employment rate for women with secondary education decreased from $79 \%$ in $1986-1990$ to $69 \%$ in $1990-1995$ and then increased to $72 \%$ in $2006-$ 2010 (percentage decrease during 1976-2010 being $10 \%)$. Among women with a college degree, the incidence rate decreased from 22 in 1976-1980 to 20 in 2006-2010, with very little variation during the study period (percentage decrease during 1976-2010 being 8\%). The employment rate for women with a college degree decreased from $88 \%$ in $1986-1990$ to $81 \%$ in $1990-1995$ and then increased to $84 \%$ in 2006-2010 (percentage decrease during 1976-2010 being 4\%).

Table 2 shows the HRs of hospitalisation adjusted for age and marital status, separately for men and women with an elementary school education and secondary education, and compares them with those of the men and women with a college degree. Among men with an elementary school education, the difference with men with a college degree remained fairly stable between 1976 and 1990 (HR 1.63 to 1.67), increased during 1991-1995 (HR 1.78), decreased during 1996-2000 (HR 1.59), and then increased between 2001 and 2010 (HR 1.94 to 2.05). Among men with secondary education, the difference with men with a college degree followed a similar secular path but with lesser variation (HR 1.39 to 1.74 ) over time.

Among women with an elementary school education, the difference with women with a college degree was rather small in 1981-1985 (HR 1.24), increased between 1986 and 1995 (HR 1.38 to 1.45 ), decreased during 19962000 (HR 1.30), and then increased between 2001 and 2010 (HR 1.36 to 1.53). Among women with secondary education, the difference with women with a college degree remained fairly stable (HR 1.12 to 1.30 ) over time.

\section{DISCUSSION}

In this study of the Finnish working-age population, we found decreasing psychiatric hospitalisation rates for men and women with secondary or higher education, and increasing hospitalisation rates for men and women with an elementary school education. In 1976-1980, the HR of psychiatric hospitalisation among men was 1.67, and among women it was 1.34 in the elementary school education group compared with the population with a college education, whereas in 2006-2010 the corresponding figures were 2.05 among men and 1.53 among women. The result supports our hypothesis: not even one of the world's most egalitarian comprehensive school systems offering uniform basic education for the whole population could prevent increasing educational inequalities in mental health outcomes in a changing political and economic context.

The main mechanism behind the diverging long-term trends in psychiatric hospitalisation is likely to be the more starkly decreasing employment rate of those with only an elementary school education, leading to low income, job insecurity and narrowing social participation. In 1986-1990, the employment rate among men 


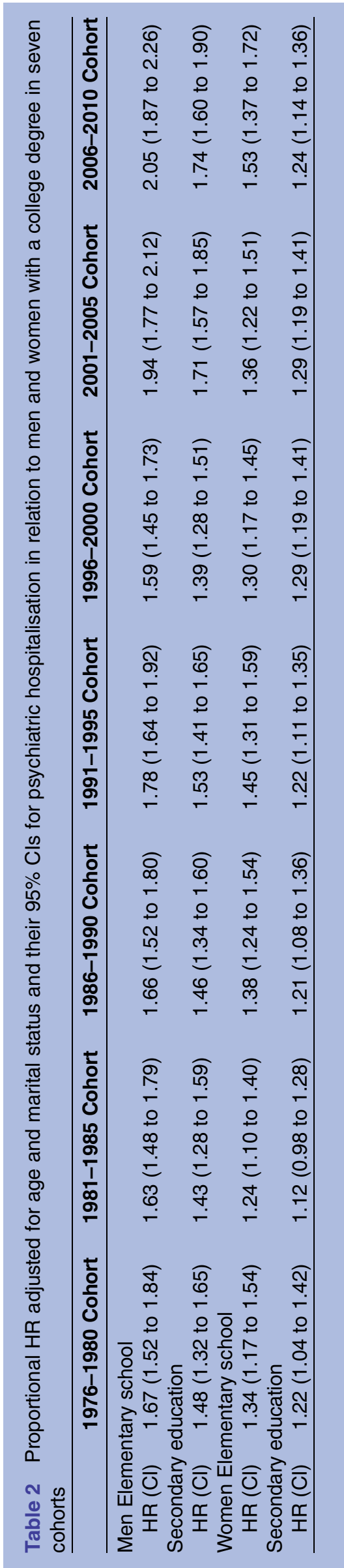

was 1.3-fold, and among women it was 1.4-fold in the college educated group compared with the population with only an elementary school education, whereas in 2006-2010 the corresponding figures were 1.5 among men and 1.7 among women. During the deep economic crisis in Finland at the beginning of the 1990s, psychiatric hospitalisation increased the most among men with an elementary school education, as a massive loss of blue-collar jobs took place in traditional male industries such as manufacturing and construction. ${ }^{20}{ }^{25}$ During the global economic recession after 2008, the decreasing employment rate has been a likely contributor to increasing hospitalisation for psychiatric disorders among men and women with an elementary school education.

A secondary mechanism accelerating the diverging long-term trends in psychiatric hospitalisation between populations with different educational credentials is employment-dependent access to outpatient mental health services. Almost $90 \%$ of the Finnish working population is offered occupational health services (including prescribing and occupational psychologist services) with short waiting times and completely free of charge. ${ }^{37}$ The non-working population is excluded from these services and limited to municipal mental health services, with internationally comparable high client fees and long waiting times, ${ }^{38}$ unless they can afford to buy out-of-pocket services from the private sector. The occupational health services are subsidised by tax-like funding via the Social Insurance Institution of Finland, and their volume and expenditure increased 5-fold between 1975 and 2010. ${ }^{37}$ In contrast, the municipal services financed mainly by municipal taxation and state taxation faced severe austerity policies in most parts of Finland in the beginning of the $1990 \mathrm{~s}^{20}{ }^{21}$ and never fully recovered before the next big hit of the global economic recession of 2008. ${ }^{39}$ It is most likely that psychiatric hospitalisation has become an outcome of lack of primary mental healthcare among the non-working population with low educational credentials.

The third mechanism, welfare cuts (cuts in unemployment benefits, sickness allowances and medicine reimbursements), ${ }^{14} 22$ made losing a job and losing access to occupational health services even more damaging for mental health during the economic crisis of the 1990s. The fourth mechanism, reduction of alcohol duty in 2004, increased drinking and alcohol-related harms; the effect was largest among those with low educational credentials, particularly those outside the core labour force. ${ }^{35}$

The fifth mechanism behind the diverging long-term trends in psychiatric hospitalisation might be related to the decreasing number of the working-age population with only an elementary school education. Even if we found no scientific evidence to suggest that this group would have become more selective over the past four decades, it may well be so, as back in the 1970s, twothirds of the population aged 30-65 years had only an 
elementary school education, compared with only about one-fifth in the 2000s. This might suggest that the population with only an elementary school education has become more determined by their mental health and mental health supporting environment during childhood, as previous studies have found that psychiatric disorders during adolescence may affect education, ${ }^{40}{ }^{41}$ as well as labour market position at young adulthood ${ }^{42}$ and at later adulthood. ${ }^{43}$ However, it is crucial to note that this mechanism of health selection is not mutually exclusive with the mechanisms of low employment opportunities, lack of healthcare services and low social security, but that they are complementary and may reinforce each other. The individuals with poor mental health during childhood who obtained a low labour market position during adulthood were even more likely to be left out of work, excluded from outpatient health services, enjoy a lower level of social security, and to end up in a psychiatric hospital after the welfare state retrenchment.

All in all, our study showed that even in advanced welfare state economies like Finland, the historical points in time differ in ways that may accentuate or diminish the role of an individual's educational credentials in shaping their mental health. As researchers attempt to track evidence of the causal association between educational credentials and mental health, it is crucial to take the macro context into consideration and to draw implications from empirical results in a contextually specific manner. Recent studies using a withinmonozygotic twins method to control for unobserved factors shared by identical twins support this standpoint by indicating significant prohealth effects of education in some regional contexts ${ }^{44}$ but not in others. ${ }^{45}$ As educational inequalities do not seem to exist to the same extent within all regional and historical contexts, we propose future studies to explore further under what conditions educational credentials affect mental health, instead of just the dichotomous question of whether education is related to mental health, still nurtured by large-scale epidemiological studies. ${ }^{46}$ This kind of shift in the research question might help us to better understand the bigger picture and the mechanisms which create, eliminate, exacerbate or suppress the inequalities in specific historical and regional contexts.

For decades, public health researchers have identified social factors that explain health inequalities, some of which are amenable to policy interventions. Most of the existing public health studies, however, have focused only on the more downstream social determinants, such as interpersonal relationships. These factors, although important and amenable to study with epidemiological study designs, do not explain the root causes of health inequalities, because the inequalities are also influenced by macrolevel (political, economic, cultural) factors. ${ }^{11} 4748$ Therefore, we suggest that a greater investment in studying macrolevel determinants has a high potential to make a significant contribution to the public health agenda. This kind of perspective may even enable us to think in a way that 'transforms personal health problems into political and public issues', ${ }^{49}$ indeed the very basis for building the Finnish welfare state after World War II. ${ }^{14} 31$

The major limitations of this study are its reliance on aggregate-level data on employment rates and its inability to take all theoretically possible confounding factors, such as social support and childhood socioeconomic position, into account. In this study, we used a wide category of all hospitalisations for psychiatric disorders, as the definitions of many psychiatric illnesses lack specific biological and pathological markers and are instead based on a convergence of symptoms and familial aggregation patterns, causing different labelling for similar conditions. ${ }^{50}$ The data used in this study were based on a national sample and are well suited for epidemiological research. ${ }^{36}$ There was no loss to follow-up, except emigration from Finland. The annual number of people who emigrated from Finland varied between 5884 and 18209 during 19762010. This represents only $0.1-0.4 \%$ of the Finnish population. The changes in the ICD were recoded to correspond with the classification used in our analysis. The data used in this study cannot address the causation-selection issue of educational level and psychiatric morbidity, but this issue has been investigated elsewhere using a different study design. These studies in adult populations have shown that causation is a more powerful factor than selection, in particular with education that does not tend to change considerably over the adult life, and thus is rather immune to selection processes. ${ }^{12}$

\section{CONCLUSIONS}

The present results indicate that educational inequalities in severe mental illness have widened in the Finnish working-age population. The results showed increasing psychiatric hospitalisation rates among men and women with an elementary school education and decreasing psychiatric hospitalisation rates among men and women with secondary or higher education. The mechanisms behind these diverging long-term trends lie in the structures of the Finnish labour markets, healthcare system, welfare system and alcohol policy, and were activated by welfare state retrenchment. We conclude that together with equal opportunities for education, such as the policies introduced in Finland over the past four decades, strong labour market, healthcare, welfare and other public policies are needed in order to reduce inequalities in severe mental illness. Attention should also be given to intersectoral structures for taking inequalities into account in all policies, to raise the standing of health inequalities on the political agenda, and to induce political solutions through often contentious and divisive political policy processes.

\section{Author affiliations}

${ }^{1}$ Centre of Expertise for the Development of Work and Organizations, Finnish Institute of Occupational Health, Tampere and Helsinki, Finland

${ }^{2}$ Bloomberg Faculty of Nursing, Dalla Lana School of Public Health, University of Toronto, Toronto, Canada 
${ }^{3}$ Department of Social Research, University of Helsinki, Helsinki, Finland ${ }^{4}$ UKCRC Centre of Excellence for Public Health, Queen's University Belfast, Belfast, UK

${ }^{5}$ Faculty in Wroclaw, University of Social Sciences and Humanities, Poland

Contributors LK was involved in designing the hypothesis and drafting the manuscript for content, including analysis and interpretation of data. CM was involved in designing the hypothesis and revising the manuscript for content. AKos was involved in the analysis of data and revising the manuscript for content. AKou, PV and AV were involved in revising the manuscript for content and critically reviewing drafts of the article. All authors have approved the final version of the manuscript and agree to be accountable for all aspects of the work.

Funding The collection, analysis and interpretation of the data and the writing of the report was supported by the Academy of Finland (grant number 267 172).

Competing interests None declared.

Ethics approval The study was approved by the Ethics Committee of the Finnish Institute of Occupational Health.

Provenance and peer review Not commissioned; externally peer reviewed.

Data sharing statement The authors confirm that, for approved reasons, some access restrictions apply to the data underlying the findings. This study utilises administrative record linkage and all data used in the present manuscript were obtained from third parties. Interested researchers need to obtain these data directly from them. Data on the background characteristics of the participants were obtained from the population database maintained by Statistics Finland. The employment rates were drawn from an employment database maintained by Statistics Finland, and the dates of death were obtained from the National Death Register also kept by Statistics Finland. Hospitalisation data were obtained from the Finnish Hospital Discharge Register that is maintained by the National Institute for Health and Welfare in Finland. Record linkage was conducted by Statistics Finland. Contact details for organisations that own the data: Data on hospitalisations: National Institute for Welfare and Health Arto Vuori, Development Manager THL Information Department arto.vuori@thl.fi tel. +358 29524 7035. Other register data used in this study: Statistics Finland Registrar's Office Sanna Malinen, Statistician kirjaamo@stat.fi tel. +358 295512564.

Open Access This is an Open Access article distributed in accordance with the Creative Commons Attribution Non Commercial (CC BY-NC 4.0) license, which permits others to distribute, remix, adapt, build upon this work noncommercially, and license their derivative works on different terms, provided the original work is properly cited and the use is non-commercial. See: http:// creativecommons.org/licenses/by-nc/4.0/

\section{REFERENCES}

1. Dohrenwend BP, Levav I, Shrout PE, et al. Socio-economic status and psychiatric disorders: the causation-selection issue. Science 1992;255:946-52.

2. Muntaner $\mathrm{C}$, Eaton WW, Miech $\mathrm{R}$, et al. Socioeconomic position and major mental disorders. Epidemiol Rev 2004;26:53-62.

3. Aro S, Aro H, Salinto M, et al. Educational level and hospital use in mental disorders: a population-based study. Acta Psychiatr Scand 1995;91:305-12.

4. Faris RE, Dunham HW. Mental disorders in urban areas. Chicago, IL: University of Chicago Press, 1939.

5. Dooley D, Catalano R. Economic change as a cause of behavioural disorder. Psychol Bull 1980;87:450-68.

6. Dooley D, Fielding J, Levi L. Health and unemployment. Annu Rev Public Health 1996;17:449-65.

7. Brenner $\mathrm{MH}$. Estimating the social costs of national economic policy: implications for mental and physical health and criminal aggression. Washington, MD: US. Government Printing Office, 1976.

8. Whiteford HA, Degenhardt L, Rehm J. Global burden of disease attributable to mental and substance use disorders: findings from the Global Burden of Disease Study 2010. Lancet 2013;382:1575-86.

9. Luy M. warum Frauen länger leben-wird ein Vergleich der Sterblichkeit von Kloster- und Allgemeinbevölkerung durch Bildungsgrad un Missionstätigkeit der Ordensmitglieder beeinflusst? Zeitscrift für Bevölkerungswissenschaft 2003;28:5-35.
10. Bambra C. Work, worklessness, and the political economy of health Oxford: Oxford University Press, 2011.

11. Navarro V, Muntaner C, Borrell C, et al. Politics and health outcomes. Lancet 2006;368:1033-7.

12. Chung $\mathrm{H}$, Muntaner $\mathrm{C}$. Political and welfare state determinants of infant and child health indicators: an analysis of wealthy countries. Soc Sci Med 2006;63:829-42.

13. Esping-Andersen $\mathrm{G}$. The three worlds of welfare capitalism. Princeton, NJ: Princeton University Press, 1990.

14. Anttonen A, Sipilä J. Suomalaista sosiaalipolitiikkaa. Tampere: Vastapaino, 2000

15. Hulkko K, Pöysä J. Vakaa markka: teot ja tarinat. Jyväskylä: Atena Kustannus, 2000.

16. Ranki R. Haltia vai haltija? Harri Holkerin hallituksen talouspoliittinen ministerivaliokunta. Helsinki: Edita, 2000.

17. Kiander J, Vartia P. Suuri lama: suomen 1990-luvun kriisi ja talouspoliittinen keskustelu. Helsinki: Taloustieto, 1998

18. Häggman K, Kuisma M, Markkola $\mathrm{P}$, et al. Suomalaisen arjen suuri tarina. Helsinki: SKS, 2010.

19. Kautto M, Heikkilä M, Hvinden B, et al. Nordic social policy: changing welfare states. London: Routledge, 1999.

20. Kalela J, Kiander J, Kivikuru U, et al. Down from the heavens, Up from the ashes. The Finnish economic crisis of the 1990s in the light of economic and social research. Helsinki, Finland: Gummerus, 2001.

21. Lehto J, Blomster P. Recession in the 1990s and its policy influence on social and health care services. Yhteiskuntapolitiikka 1999;64:207-21.

22. Heikkilä M, Uusitalo H. Leikkausten hinta. Tutkimuksia sosiaaliturvan leikkauksista ja niiden vaikutuksista 1990-luvun Suomessa. Helsinki: Stakes, 1997

23. Viialainen R. Sairaille apu Suomessa jo kalliimpaa kuin USA:ssa. Dialogi 1999;9:31.

24. Blomberg $\mathrm{H}$, Kildal N. Workfare and welfare state legitimacy. Helsinki, Finland: University of Helsinki Press, 2010.

25. Järvensivu A, Kokkinen L, Kasvio A, et al. Changes at work-a challenge and an opportunity for well-being at work, careers and the quality of work life. Helsinki, Finland: Finnish Institute of Occupational Health, 2014.

26. Aho $\mathrm{S}$, Lehtonen $\mathrm{H}$. Hyvinvointivaltion leikkausten uudelleenarviointia. Janus 2000;8:97-113

27. Blom R, Melin H, Pyöriä P. Tietotyö ja työelämän muutos. Palkkatyön arki tietoyhteiskunnassa. Helsinki: Gaudeamus, 2001.

28. Blom R. Mikä Suomessa muuttui? Sosiologinen kuva 1990-luvusta. Helsinki: Gaudeamus, 1999.

29. Vähätalo K. Työttömyys ja suomalainen yhteiskunta. Tampere: Gaudeamus, 1998.

30. Blomberg $\mathrm{H}$, Hannikainen M, Kettunen P. Lamakirja. Näkökulmia 1990-Iuvun talouskriisiin ja sen historiallisiin konteksteihin. Turku Kirja-Aurora, 2002.

31. Siltala J. Työelämän huonontumisen lyhyt historia. Muutokset hyvinvointivaltioiden ajasta globaaliin hyperkilpailuun. Helsinki: Otava, 2004.

32. Kvist J, Fritzell J, Hvinden B, et al. Changing social equality: the Nordic welfare model under 21st century. Bristol, UK: The Policy Press, 2012.

33. Moisio S. Towards attractive and cost-efficient state space: politica geography of the production of state transformation in Finland. World Sci Rev 2008:4:1-34.

34. Melkas T. Health in all policies as a priority in Finnish health policy: a case study on national health policy development. Scand J Public Health 2013;41:3-28.

35. Herttua K. The effects of the 2004 reduction in the price of alcohol on alcohol-related harm in Finland: a natural experiment based on register data. Helsinki: University of Helsinki, 2010.

36. Sund R. Quality of the Finnish hospital discharge register: a systematic review. Scand J Public Health 2012;40:505-15.

37. Social Insurance Institution of Finland. Official statistics: occupational health care in 2010. Helsinki, Finland: Social Insurance Institution of Finland, 2012

38. The Organisation for Economic Co-operation and Development. $O E C D$ reviews of health systems: Finland. Paris, France: OECD Publishing, 2005.

39. Magnussen J, Vrangbaek K, Saltman RB. Nordic health care systems: recent reforms and current policy challenges. Maidenhead, UK: Open University Press, 2009.

40. Fletcher JM. Adolescent depression: diagnosis, treatment, and educational attainment. Health Econ 2008;17:1215-35.

41. McLeod JD, Fettes DL. Trajectories of failure: the educational careers of children with mental health problems. Am J Sociol 2007;113:653-701. 
42. Veldman K, Bültmann U, Stewart RE, et al. Mental health problems and educational attainment in adolescence: 9-year follow-up of the TRAILS study. PLOS ONE 2014;9:e101751.

43. Fletcher J. Adolescent depression and adult labor market outcomes. South Econ J 2013;80:26-49.

44. Behrman JR, Xiong Y, Zhang J. Cross-sectional schooling-health associations mispresented causal schooling effects on adult health and health-related behaviours: evidence from the Chinese Adults Twins Survey. Soc Sci Med 2015;127:190-7.

45. Amin V, Behrman JR, Kohler HP. Schooling has smaller or insignificant effects on adult health in the US than suggested by cross-sectional associations: new estimates using relatively large samples of identical twins. Soc Sci Med 2015;127:181-9.
46. Gakidou E, Cowling K, Lozano R, et al. Increased educational attainment and its effect on child mortality in 175 countries between 1970 and 2009: a systematic analysis. Lancet 2010;376:959-74.

47. Galea S. Macrosocial determinants of population health. New York: Springer, 2007.

48. Navarro V, Shi L. The political context of social inequalities and health. Soc Sci Med 2001;52:481-91.

49. $\mathrm{Ng} \mathrm{E}$, Muntaner $\mathrm{C}$. A critical approach to macrosocial determinants of population health: engaging scientific realism and incorporating social conflict. Curr Epidemiol Rep 2014;1:27-37.

50. Kessing LV. Validity of diagnoses and other clinical register data in patients with affective disorders. Eur Psychiatry 1998;13:392-8. 